UDC 81'255:811.111'373

DOI https://doi.org/10.32841/2409-1154.2021.47-3.45

Yarova L. O., Candidate of Pedagogical Sciences, Associate Professor at the Department of Translation, Applied and General Linguistics Volodymyr Vynnychenko Central Ukrainian State Pedagogical University

\author{
Oliinyk O.S., \\ Candidate of Philological Sciences, \\ Senior Lecturer at the Department of Translation, Applied and General Linguistics \\ Volodymyr Vynnychenko Central Ukrainian State Pedagogical University
}

\title{
LEXICAL TRANSFORMATIONS IN UKRAINIAN TRANSLATIONS OF DEFINITIONS IN EU LEGAL ACTS
}

Summary. The paper depicts the peculiarities of lexical translation transformations in Ukrainian translations of English EU legislative acts. The novelty of this study is the exploration of lexical translation transformations in the legal textual definitions as legal acts integral constituents that explicate specialist knowledge, contained in legal terms. The analysis is made on the basis of the classification of lexical translation transformations synthesized from research sources by L.S. Barkhudarov[1, p.97-105], and Ya. Recker [2, p. 38]. Using contextual analysis, contrastive method to study similarities and differences in semantic scope of legal definitions in EU legal acts within English as a source language (henceforth is SL) and Ukrainian as a target language (henceforth is TL), the following inventory of lexical translation transformations is identified that have been used to reach equivalence in translating legal definitions: loan translation $(52,31 \%$ in the TL), concretization $(20,84 \%)$, explicatory translation $(6,95 \%)$, modulation $(6,02 \%)$, transcription (5,09\%), transliteration $(4,63 \%)$, adaptation $(2,31 \%)$, and generalization $(1,85 \%)$. Each of the above lexical translation transformations is illustrated with examples from our random selection of EU legal acts belonging to the acquis that Ukraine as a potential EU candidate is obliged to translate to harmonize its national legislation. Quantitative evaluation method has shown that slightly above two thirds (73\%) of all lexical translation transformations in Ukrainian translations of legal definitions from our observation corpus is made up by the two types: loan translation, and concretization, whereas modulation, transcription, transliteration, adaptation, and generalization taken together constitute a bit more than one-fourth $(27 \%)$ of all lexical transformations under analysis. Loan translation is primarily used for translating numerous terminological word combinations as constituents of legal definitions. Frequent use of concretization can be explained by the necessity of adequate and effective semantic rendering of legal definitions content.

Key words: lexical translation transformations, legal definitions, EU legislative acts.

Introduction. European Union (henceforth is EU) legislative acts represent a salient group of EU texts, showing the autonomy of EU law, the uniqueness of its source system, and the significant difference between EU law sources and international public law sources [3, p. 84]. To adequately reflect the text content, the meaning of the terms should be taken into account, since the objective reality described in a text is fixed in their meanings explicated by textual definitions [4, p. 40].
The accuracy of translation of definitions as means of legal terms semanticization in legislative texts becomes vitally important because adequate understandability of their content is provided precisely by the legal definition, a general verbal formula that contains the distinctive and essential features of legal concepts/notions [5, p. 68].

The analysis of publications on linguistic and translation issues of EU legislative texts indicates that Ukrainian researchers are focusing their scholarly efforts on the genre and lexical and semantic features of legal acts structure [3], on lexical harmonization in the context of Ukraine's European integration [6], on relevant issues concerning terminology translation [7, p. 306-307], but the characteristic features of translation transformations of legal definitions received insufficient coverage in research sources.

Following the above said, this paper aims to identify and describe the types of lexical translation transformations that have been used to reach equivalence in EU legal acts within English and Ukrainian. We will first present some theoretical considerations related to $E U$ legal acts, legal definitions, and lexical translation transformations. Against this background, we will next describe the peculiarities of lexical translation transformations in legal definitions of EU legal acts in English and Ukrainian.

Recent research and publications. Multilingualism as a defining feature behind EU legal culture conditions an inevitable presence of translation and translators [8]. In 2004, the Verkhovna Rada of Ukraine approved the National Program of adaptation of Ukrainian legislation to the European Union laws [9]. The purpose of adapting Ukrainian laws to EU laws involves the process of Ukrainian legal system alignment with acquis communautaire. Harmonization of Ukraine's national legal system with that of EU necessitates the translation of EU's legal acts into Ukrainian, and this need, in its turn, makes the legal, linguistic, and translation research of legal documents from the acquis communautaire a topical issue.

Legal definition represents the understanding (characteristics) of legal phenomena, indicated by the corresponding legal term through the allocation of their main features [10, p. 44]. The main function of definitions is to ensure clarity and mutual understanding of prescriptions made by legislators.

In the research literature, various classifications of legal definitions are suggested. Drozdova distinguishes the following types of legal definitions: definition-word, i. e. the definition equivalent of a single word; definition-phrase, i.e. the definition equivalent of a separate 
compound or complex sentence; definition-description, i.e. the definition equivalent of several sentences that explain one term [11, p. 66].

Benion singles out six types of legal definitions that are not only allowed by law but also regulated by it and therefore they are called statutory: comprehensive, clarifying, representative, referential, enlarging, labeling, and exclusionary [12, p. 132]. Comprehensive definitions always include the full meaning of a word taking into account all its components, e. g., "economic operator" means any natural or legal person, or a contracting entity, or a group of such persons and/or entities, including any temporary association of undertakings, which offers the execution of works and/or work, the supply of products or the provision of services on the market [13]. Clarifying definitions specify the meaning components of the signified word, taking the form "T means A, B, C or D, or any other manifestation of T": "label requirements" means the requirements to be met by the works, products, services, processes or procedures in question to obtain the label concerned [13]. In enlarging definitions, certain components are added to the meaning of the word, taking the form "T includes X", e. g., "harmful organism" means an organism, including pathogenic agents, which has an unwanted presence or a detrimental effect on humans, their activities or the products they use or produce, on animals or the environment [13]. Labeling definitions have two necessary components: "labeling term" + "concept-explanation" corresponding to it, e. g., "tenderer" means an economic operator that has submitted a tender [13]. Referential definitions are used when the meaning of the term is already defined in another legal act, e. g., "central purchasing body" means a contracting entity within the meaning of Article 4(1) of this Directive or a contracting authority within the meaning of point 1 of Article 2(1) of Directive 2014/24/EU providing centralized purchasing activities and, possibly, ancillary purchasing activities [13]. Exclusionary definitions deprive the term of certain meaning components, e. g., "support vessel" means a vessel other than a craft carried on board that is not equipped with operational fishing gear designed to catch or attract fish and that facilitates, assists, or prepares fishing operations [14].

In creating an equivalence between a source text (henceforth is ST) and a target text (henceforth is TT), translators apply various translation transformations [1, p. 191]. In the focus of our attention, there are lexical translation transformations. Based on various classifications of lexical translation transformations described in research sources we have synthesized their typology consisting of loan translation, transcription, transliteration that mainly deal with finding the equivalence of form, and generalization, concretization, explicatory translation, modulation, and adaptation aiming at reaching the equivalence of meaning.

Research methodology and design. An analysis of the EU legal acts translations from English into Ukrainian was made to explore the usage of lexical translation transformations in the above-said translations. While conducting the analysis, a research question to answer is about the types and impact of lexical transformations in legal definitions translations of the EU legislative acts to show how to overcome some of the lexical inconsistencies and to outline the basic nomenclature of translation transformations.

To study the lexical choices of reaching translation equivalence, a parallel corpus consisting of 5 English EU legislative acts and their Ukrainian translations is used. In most cases, definienda (a term/terminological expressions that are being defined) consist of two to four elements, e. g., fishing operation; mineral supply chain; Union fishing authorizations database, etc., with the two-member phrases predominating. In some cases, the definiendum can consist of a noun and two compound adjectives in the attributive function, e. g. conflictaffected and high-risk areas, or two nouns with attributes, e. g. global responsible smelters and refiners. In rare cases, the definiendum can be of "X or Y" structure, e. g. chain of custody or supply chain traceability system. The definiens (a stretch of text that defines) in legal definitions of EU legislative texts can be predominantly patterned as a simple extended sentence, e. g. "verifiable date" means a date which can be verified by the inspection of physical date stamps on products or of inventory lists [15]; and more than one extended sentence, e. g. "recycled metals" means reclaimed end-user or post-consumer products, or scrap processed metals created during product manufacturing, including excess, obsolete, and scrap metal materials which contain refined or processed metals that are appropriate for recycling in the production of tin, tantalum, tungsten or gold. For the purposes of this definition, minerals partially processed, unprocessed or a by-product from another ore are not considered to be recycled metals [15].

The methodology of this study includes the following key methods: the method of contextual analysis to identify the meaning of a certain legal term or phrase within the legal definition, contrastive method to study differences in the semantic scope of legal definitions, transformational analysis to establish peculiarities and types of lexical transformations in EnglishUkrainian legal definitions translation, descriptive method to depict collected factual data, quantitative evaluation method to identify the frequency of occurrence of each type of lexical transformations.

Findings and discussions. By way of the quantitative evaluation method, we determined the frequency of occurrence of each lexical transformation type in the Ukrainian translations of EU legislative acts from our observation corpus (see fig. 1). As shown by our data, loan translation is the most frequent lexical transformation occurring in the EU legislative texts (113 units or $52,31 \%$ in TL); the second place is taken by concretization (45 units or $20,84 \%$ ); the third place - by explicatory translation (15 units or $6,95 \%)$; the fourth place - by modulation (13 units or $6,02 \%$ ); the fifth place - by transcription (11 units or 5,09\%); the sixth place - by transliteration (10 units or 4,63\%); the seventh place by adaptation ( 5 units or 2,31\%), and the last place is occupied by generalization (4 units or 1,85\%).

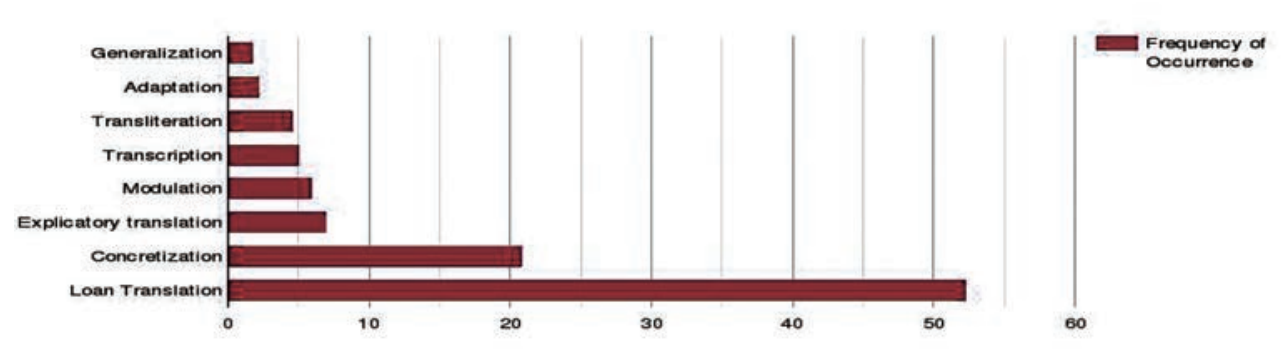

Fig. 1. Lexical transformations in the definitions of EU legislative acts 
Let us consider the transformations that are used in legal definitions of Ukrainian translations of English EU legislative acts in more detail.

Loan translation $(52,31 \%$ in TL) is a transformation used to translate lexical units of the SL by replacing their components in the target language. This type of transformation is most frequently used in the EU legal acts. For instance, the terminological combination "member states" [16] is rendered into Ukrainian as "держави-члени" [17]; the notion "biometric data" [18] is translated into Ukrainian as "біометричні дані" [19]. This lexical transformation conveys the full meaning of a terminological unit without omitting any components of a concept/notion.

In approximately one-fifth of all legal definitions ( $20,84 \%$ cases in TL) under analysis in EU legislative acts texts concretization is used, where the word with a broad semantics/meaning in the ST is replaced by a word with a narrower semantics/meaning, e. g., the word "body" [20] (organization, main part) is translated into Ukrainian exactly as "opzaн" [17] - the translator narrowed the meaning of this concept/ notion. In another example, the word "Union" [21] is rendered not as "association" but specified as " $E C$ " [22].

Let us consider one more example that illustrates the application of concretization. In the legal definition (see example 1), the word "measure" (method, activity, arrangement) is presented in the TT as "інструмент" (a means of pursuing an aim). Using this concept/ notion, the translator explains that the definition refers not to a plan or course of action for protecting personal data, but to concrete tools (technical and organizational) for achieving this aim, thus narrowing the meaning of this term.

Example 1:

\begin{tabular}{|c|c|}
\hline "pseudonymisation" & “використання \\
\hline the processing & німів" означае опрач \\
\hline of personal data in such & персональних даних у такий \\
\hline a manner that the personal data & спосіб, щзо персональні дані \\
\hline can no longer $b$ & більше не м \\
\hline to a specific data subject & конкретного суб'єкта даних \\
\hline without the us & без використання додаткової \\
\hline information, provided that & а умови, що таку \\
\hline $\begin{array}{l}\text { kept separately and is subject } \\
\text { such a }\end{array}$ & $\begin{array}{l}\text { оооаткову Інформацию зоерта- } \\
\text { ють окремо і на неї поширю- }\end{array}$ \\
\hline to technical and organisation & ється застосування технічних \\
\hline measures to ensure that & та організаційних інструмен- \\
\hline ta are not & гечення того, що \\
\hline $\begin{array}{l}\text { identifiable natural person } \\
{[18] \text {. }}\end{array}$ & $\begin{array}{l}\text { персональнl оани не віонесено } \\
\text { до фізичної особи, яку іденти- } \\
\text { фіковано чи можна ідентифі- } \\
\text { кувати [19]. }\end{array}$ \\
\hline & \\
\hline
\end{tabular}

The third place according to its frequency of occurrence in our observation corpus of EU legal acts is taken by explication or descriptive translation $(6,95 \%$ in TT). This transformation means that the term used in the SL is replaced by a terminological phrase that defines this concept in the TL, e. g. the translator explains the phrase "entity in charge of maintenance" [16] in Ukrainian, with the help of a descriptive phrase - "суб'єкт, який вiдповiдає за технічне обслуговування" [17], by adding the words "який" and " $3 \mathrm{a}$ ".

The lexical translation transformation of modulation or semantic matching (6,02\% in TT) allows to replace the word or phrase in the SL with the language unit of the TL, the meaning of which is logically deduced from the meaning of the source terminological unit.

In the following definition (see example 2), the translator uses modulation to render the concept "breach" (break, gap, fall). In the Ukrainian TT, this word is translated with the phrase "порушення захисту персональних даних" (that is, hacking, illegal intrusion, attack), because according to the definition, this concept means "a gap in a defense of personal data or a gap in the defense of their security which leads to their destruction, loss, alteration, unauthorized disclosure or access".

Example 2:

\begin{tabular}{|l|lr|}
\hline \multicolumn{2}{|c|}{ "personal data breach" } & \multicolumn{2}{|c|}{ "порушення захисту } \\
means a breach of security & персональних даних" озна- \\
leading to the accidental or & чає порушення безпеки, шзо \\
unlawful destruction, loss, & призводить до випадкового \\
alteration, & unauthorised & чи незаконного знищення, \\
disclosure of, or access to, & втрати, зміни, несанкиі- \\
personal data transmitted, & онованого розкриття або \\
stored or otherwise processed & доступу до персональних \\
[18]. & даних, які передано, збере- \\
& жено або іншим чином опра- \\
& цьовано [19]. \\
\hline
\end{tabular}

Lexical transformations of transcription $(5,09 \%$ in TL) and transliteration ( $4,63 \%$ in TL), i.e. ways of translating the lexical unit of the SL by reconstructing its form using sounds or letters of the TL, exhibit nearly the same frequency of occurrence in our observation corpus (see examples below).

\begin{tabular}{|l|l|}
\hline English terms in the ST & Their Ukrainian equivalents in the TT \\
\hline monosaccharide [21] & моносахарид [22] \\
\hline nanomaterial [21] & наноматеріал [22] \\
\hline controller [21] & контролер [22] \\
\hline
\end{tabular}

As it can be seen from the above-given examples, transcription or transliteration are resorted to in case of scientific terms (chemical, physical, medical, etc.), e. g. monosaccharide, nanomaterial, or in case of internationalism, i.e. words that are borrowed in more than one language, e. g. profiling, monitoring, controller, etc.

Due to a large amount of information on various topics in the EU legislative acts, such texts contain abbreviations of complex lexical units (names of different international organizations). It was found out that in Ukrainian there are two ways of rendering the abbreviations of institutions, organizations, and enterprises: transliteration of the abbreviation, e. g., SL-TL: $E C-C C, E E C-$ $E E C$; the abbreviation is formed using the Ukrainian (TL) equivalent name, e. g., SL-TL: BAT - HHT, CSM - M33, CST - Ц3Б.

Adaptation (2,31\% in TT) is the lexical transformation by way of which, the unknown language units of the SL are replaced with those which are known in the TL.

In example 3, the terminological phrase "systematic internalizer" in the SL is adapted as "систематичний учасник" in the TL, though the Ukrainian "учасник" does not accurately reflect the TL component "internalizer". In our opinion, adaptation, in this case, does not appear a translator's successful solution. This situation is complicated by the fact that the term "internalizers" is used in psychology where it denotes individuals "assuming that the focus of control over their lives is in themselves and try harder to change themselves and their environment" (Psychology Dictionary). Thus, 
the adaptation of the SL "systematic internalizer" into the TL “систематичний учасник” should be reinforced with explication. Example 3:

\begin{tabular}{|c|c|}
\hline $\begin{array}{l}\text { "systematic internaliser" } \\
\text { means an investment firm which, } \\
\text { on an organised, frequent sys- } \\
\text { tematic and substantial basis, } \\
\text { deals on own account when } \\
\text { executing client orders outside } \\
\text { a regulated market, an MTF } \\
\text { or an OTF without operating } \\
\text { a multilateral system [23]. }\end{array}$ & $\begin{array}{l}\text { "систематичний учас- } \\
\text { ник”- - інвестиційна фірма, } \\
\text { яка веде торгівлю за влас- } \\
\text { ний рахунок на організова- } \\
\text { ній, частій, систематичній } \\
\text { та істотній основі, викону- } \\
\text { ючи замовлення клієнтів поза } \\
\text { регульованим ринком, БТм } \\
\text { або ОТм без організаиії бага- } \\
\text { тосторонньої системи [24]. }\end{array}$ \\
\hline
\end{tabular}

The least common lexical transformation in translating the legal definitions in EU legislative acts is generalization (1,85\% in TL) that expands the meaning of the word. In example 4 below, the translator generalized the noun "service" and rendered it in the target text as "перевезення", but not as "обслуговування, послуга".

Example 4:

\begin{tabular}{|l|l|}
\hline "Type of operation" means & "Tuп діяльності" означає \\
the type characterised by pas- & тип, шуо характеризується \\
senger transport, including or & пасажирськими перевезен- \\
excluding high-speed services, & нями, у тому числі наявністю \\
freight transport [16]. & чи відсутністю високошвид- \\
& кісних перевезень, вантаж- \\
& ними перевезеннями [17]. \\
\hline
\end{tabular}

This study attempted to investigate lexical transformations in translations of legal definitions in the EU English legislative acts into Ukrainian. Data analysis showed that the following types of lexical transformations were resorted to when creating an equivalence between English legal definitions in EU legislative acts: loan translation, concretization, explicatory translation, modulation, transcription, transliteration, adaptation, and generalization. As to the preference of the above used transformations from the most to the least frequent, approximately $73 \%$ of them consist of loan translation (52,31\% in TL) and concretization (20,84\% in TL). The high frequency of that method application can be explained by a considerably large number of terminological phrases as definienda that already exist in the TL as lexical borrowings or there are full equivalents to the expressions from the SL; in addition to definienda consisting of one element expressed by scientific, economic, chemical, etc., terms that belong to internationalisms.

Arelatively high proportion of cases of concretization in translated legal definitions in Ukrainian as the TL can be accounted for by the legal nature of translated documents with strong demands on their understandability and accuracy. Another reason for it is that English is characterized by a larger amount of substance names, process names, words with a wide semantic basis in comparison with Ukrainian, thus their translation depends to a great extent on the concretization of their meaning. For the same reason, in contrast to concretization, generalization is sparingly used in the translation of legal definitions into Ukrainian. Explicatory translation and modulation, in our opinion, are used in cases where there is partial or no equivalence between the definienda in English and Ukrainian.

Conclusions. The legal definition alongside the legal term is a core unit of storing information and actualizing specialist (legal) knowledge incorporated in legal texts. This study aimed at identifying and describing the types of lexical translation transformations that have been used to reach equivalence in EU legal acts within English as a SL and Ukrainian as a TL. The major findings of the study consist in establishing an inventory of lexical transformations in translations of legal definitions that incorporates the following eight types: loan translation $(52,31 \%)$, concretization $(20,84 \%)$, explicatory translation $(6,95 \%)$, modulation $(6,02 \%)$, transcription $(5,09 \%)$, transliteration $(4,63 \%)$, adaptation $(2,31 \%)$, and generalization $(1,85 \%)$. As shown by our quantitative data, lexical transformations exhibit different frequencies of occurrence, with loan translation and concretization being the most common, and adaptation and generalization the least common. The choice of a definite lexical transformation is primarily conditioned by similarities or differences between the SL and TL lexical components that undergo translation. The findings of this study will presumably assist legal translators and scholars, translation students in getting deeper awareness of textual legal definitions as an object of translation/research, and lexical translation transformations as tools of creating faithful translations of legal texts.

\section{References:}

1. Бархударов Л.С. Язык и перевод: вопросы общей и частной теории перевода. Москва : Международные отношения, 1975. 240 с.

2. Рецкер Я.И. Теория перевода и переводческая практика: очерки лингвистической теории перевода. Москва : Международные отношения, $1974.216 \mathrm{c}$.

3. Форманюк В.В. Система джерел права Європейського Союзу. Південноукраӥнський правничий часопис. 2015. № 2. С. 83-88.

4. Кузнецова Ю.М. Дефиниция как компонент содержательной структуры научного текста. Искусственный интеллект и принятие решений. 2016. № 1. С. 3-8.

5. Губаева Т.В. Язык и право. Москва : Норма, 2007. 160 с.

6. Касяненко Д.С. Особливості перекладу та лексичної гармонізації законодавчих актів ЄС в контексті євроінтеграції України : дис. ... канд. філол. наук : 10.02.16. Київ, 2001. 257 с.

7. Гладченко А.М., Комарова О.С. Актуальні питання перекладу термінології ЄС. Наукові записки Наиіонального університету «Острозька академія». 2013. № 36. С. 306-307.

8. Acquis communautaire. URL: https://www.eurofound.europa. eu/observatories/eurwork/industrial-relations-dictionary/acquiscommunautaire.

9. Про Загальнодержавну програму адаптації законодавства України до законодавства Європейського Союзу : Закон України від 18 березня 2004 р. № 1629-IV / Верховна Рада України. Відомості Верховної Ради Украӥни. 2004. № 29. Ст. 367. URL: https://zakon.rada.gov.ua/laws/show/1629-15\#Text.

10. Косович В.М. Правові дефініції як засіб забезпечення створення досконалих нормативно-правових актів України. Вісник Львівського університету. 2013. № 57. С. 43-52.

11. Дроздова Т.В. Научный текст и проблемы его понимания (на материале англоязычных экономических текстов) : автореф. дисс. ... докт. филол. наук : $10.02 .19 ; 10.02 .04$; Ин-т языкознания РАН. Москва, 2003. 45 с.

12. Bennion F.A.R. Bennion on Statute Law. $3^{\text {rd }}$ ed. Harlow : Longman, $1990.373 \mathrm{p}$.

13. Directive 2014/25/EU of the European Parliament and of the Council of 26 February 2014 on procurement by entities operating in the water, energy, transport and postal services sectors and repealing Directive 2004/17/EC (Text with EEA relevance). URL: https://eur-lex.europa. eu/legal-content/EN/TXT/PDF/?uri=CELEX:32014L0025\&from=ES.

14. Regulation (EU) 2017/2403 of the European Parliament and of the Council of 12 December 2017 on the sustainable management 
of external fishing fleets, and repealing Council Regulation (EC) № 1006/2008. URL: http://data.europa.eu/eli/reg/2017/2403/oj.

15. Regulation (EU) 2017/821 of the European Parliament and of the Council of 17 May 2017 laying down supply chain due diligence obligations for Union importers of tin, tantalum and tungsten, their ores, and gold originating from conflict-affected and high-risk areas. URL: http://data.europa.eu/eli/reg/2017/821/oj.

16. Decision № 1082/2013/EU of the European Parliament and of the Council of 22 October 2013 on serious cross-border threats to health and repealing Decision № 2119/98/EC (Text with EEA relevance). URL: https://eur-lex.europa.eu/legal-content/EN/ TXT/?uri=CELEX\%3A32013D1082.

17. Рішення Європейського Парламенту і Ради № 1082/2013/ЄС від 22 жовтня 2013 р. про серйозні транскордонні загрози здоров'ю та скасування Рішення № 2119/98/EC. URL: https://www.kmu.gov.ua/ storage/app/media/uploaded-files/10822013es.pdf.

18. Regulation (EU) 2016/679 of the European Parliament and of the Council of 27 April 2016 on the protection of natural persons with regard to the processing of personal data and on the free movement of such data, and repealing Directive 95/46/EC (General Data Protection Regulation). URL: https://eur-lex.europa.eu/eli/reg/2016/679/oj.

19. Регламент Європейського Парламенту і Ради (ЄС) 2016/679 від 27 квітня 2016 р. про захист фізичних осіб у зв'язку з опрацюванням персональних даних і про вільний рух таких даних та про скасування Директиви 95/46/ЄС (Загальний регламент про захист даних). URL: https://zakon.rada.gov.ua/laws/show/984_008-16.

20. Council Directive 96/29/Euratom of 13 May 1996 laying down basic safety standards for the protection of the health of workers and the general public against the dangers arising from ionizing radiation. URL: https://eur-lex.europa.eu/legal-content/EN/ TXT/?uri=CELEX\%3A31996L0029.

21. Directive 2001/18/EC of the European Parliament and of the Council of 12 March 2001 on the deliberate release into the environment of genetically modified organisms and repealing Council Directive 90/220/EEC - Commission Declaration. URL: https://eur-lex.europa. eu/legal-content/EN/TXT/?uri=CELEX\%3A32001L0018.

22. Директива Європейського Парламенту і Ради 2010/75/ЄС від 24 листопада 2010 р. про промислові викиди (інтегрований підхід до запобігання забрудненню та його контролю). URL: http://old. minjust.gov.ua/file.

23. Directive 2014/65/EU of the European Parliament and of the Council of 15 May 2014 on markets in financial instruments and amending Directive 2002/92/EC and Directive 2011/61/EU(recast). URL: https:// eur-lex.europa.eu/legal-content/EN/TXT/PDF/?uri=CELEX:32014L0 $065 \&$ from $=\mathrm{EN}$.

24. Делегований Регламент Комісії (ЄС) 2017/569 від 24 травня 2016 р. на доповнення Директиви 2014/65/ЄС Європейського Парламенту і Ради стосовно регуляторних технічних стандартів щодо призупинення торгів фінансовими інструментами та зняття фінансових інструментів 3 торгів. URL: https://zakon.rada.gov.ua/ laws/show/984_017-16.

Ярова Л. О., Олійник О. С. Лексичні трансформації в українських перекладах визначень законодавчих актів $\mathrm{EC}$

Анотація. У статті висвітлено особливості лексичних перекладацьких трансформацій в українських перекладах англійських законодавчих актів Європейського Союзу. Новизна полягає в дослідженні лексичних перекладацьких трансформацій у правових дефініціях як складових частин законодавчих актів, що експлікують спеціальні знання, закладені у правових дефініціях. Аналіз проводиться на основі класифікації лексичних перекладацьких трансформацій, синтезованої з дослідницьких робіт Л.С. Бархударова [1, с. 97-105] та Я.І. Рецкера [2, с. 38]. 3 використанням контекстуального аналізу та контрастивного методу для вивчення схожостей і відмінностей у семантичному обсязі правових дефініцій у законодавчих актах Європейського Союзу в англійській мові як мові оригіналу та українській мові як мові перекладу виявлено такі лексичні перекладацькі трансформації, які використовувалися для досягнення еквівалентності під час перекладу правових дефініцій: калькування $(52,31 \%$ в мові перекладу), конкретизація $(20,84 \%)$, описовий переклад $(6,95 \%)$, смисловий розвиток $(6,02 \%)$, транскрипція $(5,09 \%)$, транслітерація $(4,63 \%)$, адаптація $(2,31 \%)$ та генералізація $(1,85 \%)$. Кожна 3 наведених вище лексичних перекладацьких трансформацій проілюстрована прикладами з випадкової вибірки законодавчих актів acquis Європейського Союзу, які Україна як потенційний кандидат на членство в Свропейському Союзі зобов'язана перекладати для гармонізації свого національного законодавства. Метод кількісної оцінки показав, що понад дві треті (73\%) всіх лексичних перекладацьких трансформацій в українських перекладах правових дефініцій із нашого дослідницького корпусу становлять два типи - калькування та конкретизація. Натомість смисловий розвиток, транскрипція, транслітерація, адаптація та генералізація разом узяті становлять трохи більше чверті (27\%) всіх проаналізованих лексичних трансформацій. Калькування використовується здебільшого для перекладу численних термінологічних словосполучень як складників правових дефініцій. Часте використання конкретизації зумовлене необхідністю адекватної й ефективної передачі смислового змісту правових дефініцій.

Ключові слова: лексичні перекладацькі трансформації, правові дефініції, законодавчі акти Європейського Союзу. 